\title{
2D Modeling of Flood Propagation due to the Failure of Way Ela Natural Dam
}

\author{
Bagus Pramono Yakti ${ }^{1, *}$, Mohammad Bagus Adityawan ${ }^{2}$, Mohammad Farid ${ }^{2}$, Yadi Suryadi ${ }^{2}$, Joko Nugroho ${ }^{2}$ and Iwan \\ Kridasantausa Hadihardaja ${ }^{1}$ \\ ${ }^{1}$ Graduate School of Civil Engineering, Institut Teknologi Bandung, Jalan Ganesha 10, Bandung 40132, Indonesia \\ ${ }^{2}$ Water Resources Engineering Research Group, Institut Teknologi Bandung, Jalan Ganesha 10, Bandung 40132, Indonesia \\ ${ }^{3}$ Water Resources Development Center, Institut Teknologi Bandung, Jalan Ganesha 10, Bandung 40132, Indonesia
}

\begin{abstract}
A dam break induced-flood propagation modeling is needed to reduce the losses of any potential dam failure. On the 25 July 2013, there was a dam break generated flood due to the failure of Way Ela Natural Dam that severely damaged houses and various public facilities. This study simulated the flooding induced by the failure of Way Ela Natural Dam. A two-dimensional (2D) numerical model, HEC-RAS v.5, is used to simulate the overland flow. The dam failure itself is simulated using HECHMSv.4. The results of this study, the flood inundation, flood depth, and flood arrival time are verified by using available secondary data. These informations are very important to propose mitigation plans with respect to possible dam break in the future.
\end{abstract}

\section{Introduction}

Way Ela Dam was a dam located in Negeri Lima Village, Leihitu District, Ambon Island. This dam was formed naturally by landslide due to high rainfall on 13 July 2012 [1]. Avalanche material was carried in the form of soil and rocks with a very large volume, thus closing the flow of the Way Ela River. The avalanche caused the formation of a dam on Way Ela River.

A year after it was formed, on 25 July 2013 flooding occurred due to an extreme rainfall that caused the failure of the natural dam. According to Badan Nasional Penanggulangan Bencana (BNPB), the generated flood depth was about 6-7 $\mathrm{m}$ and took the lives of 1 person while the number of refugees reached to 3,000 people. The flood caused by the failure of the natural dam at least destroyed more than 350 housing units and other public facilities.

The climate change that causes extreme rainfall, has increased the frequency of floods, landslides, and increasing disaster risks caused by a dam failure [2]. Modeling the dam failure and the impact of the flood is necessary to reduce losses from the potential for dam failure [3]. A numerical model is often used to predict the flood propagation due to a dam failure, but the model used is generally still 1-D, so the distribution of inundation can not be predicted accurately. However the 1-D model approach can be used for certain cases, mostly used in channel planning, but it has limitations on runoff analysis [4]. At the time the water starts to overflow to surface, 2$\mathrm{D}$ phenomenon occurs. Therefore, it is necessary to have the calculation of the area of inundation, water level inundation, and rapid flood flooding (flood travel time). By conducting such analysis, the disaster risk of the affected area can be known [5].
Way Ela dam failure was studied and modeled using Zhong Xing HY21 [6]. The study was based on the assumption that the dam failure was caused by middle piping due to a PMF (Probable Maximum Flood) discharge, although it was mentioned that the inflow during the incident was not due to a PMF discharge. Additionally, based on investigation report [7], the cause of the dam failure was overtopping. Therefore it is necessary to conduct research based on the latest data from investigation report [7]

HEC-RAS v. 5 is a numerical software model with a free license that has been widely used to simulate flood. Starting from v.5, the model is capable of simulating 2D flow, which gives it an advantage for estimating flood inundation. The model was developed based on the full 2D St. Venant equations, solved using a finite difference scheme. The model is robust and accurate. The model was applied for simulating Monticello Dam Breach with good results [8].

In this study, 2-D modeling of flood propagation caused by the failure of the Way Ela natural dam is conducted in order to predict the flood inundation, flood depth and flood arrival time so that it can anticipate and reduce the human-economic losses . The modeling is based on the failure information that has occurred and the DEM (Digital Elevation Model) data. A two-dimensional (2D) numerical model, HEC-RAS v.5, is used to simulate the overland flow. The dam failure itself is simulated by using HECHMSv.4.

\section{Methodology of study}

The flow chart of this study is given in Figure 1.

\footnotetext{
${ }^{*}$ Corresponding author: bagusyakti@gmail.com
} 


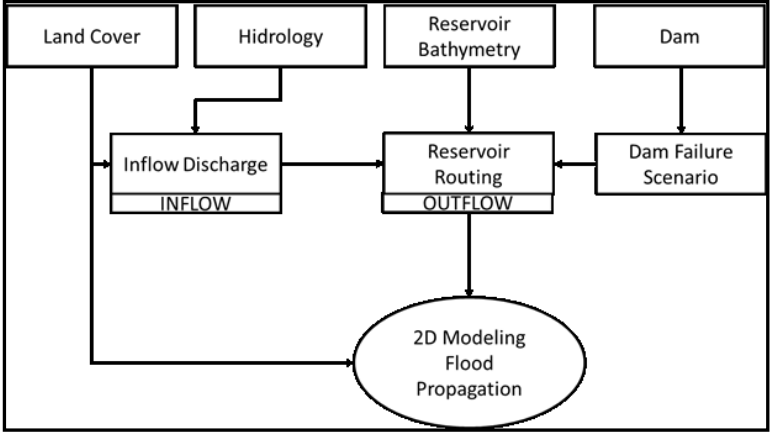

Fig. 1. Flow chart.

Land Cover was analyzed to obtain the runoff coefficient and manning's $n$ value for the inflow discharge hydrograph. Hydrological parameter was analyzed to obtain the inflow discharge hydrograph as the input for reservoir routing the dam failure outflow. Reservoir bathymetry was analyzed for reservoir routing as the parameter of reservoir storage characteristic. Dam parameter was analyzed with the reservoir routing as the parameter for dam characteristic and dam failure scenario.

\subsection{Study Area}

Way Ela Natural Dam is located in Negeri Lima Village, Leihitu District, Ambon Island. The village had a mean elevation between 0-700 $\mathrm{m}$ above sea level. The main River are the Way Ela River which in 2012 dammed to form a natural dam due to avalanches.

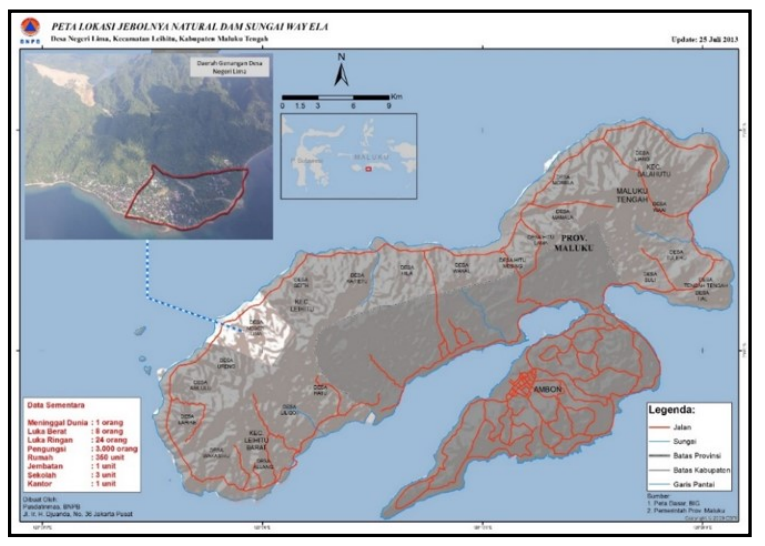

Fig. 2. Study area. BNPB [1]

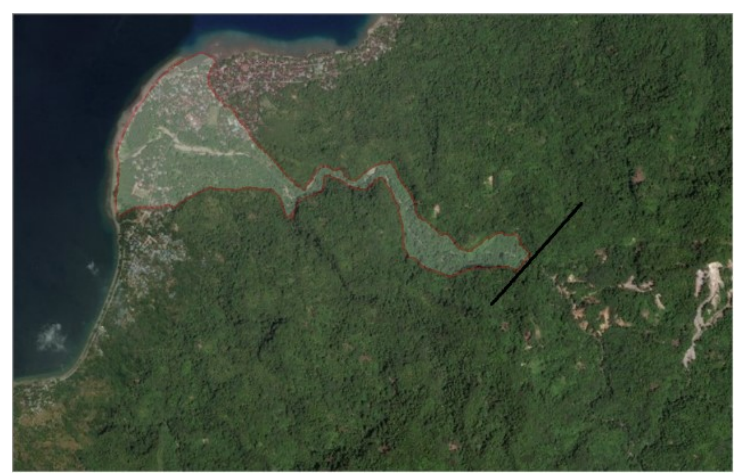

(a) Before dam failure.

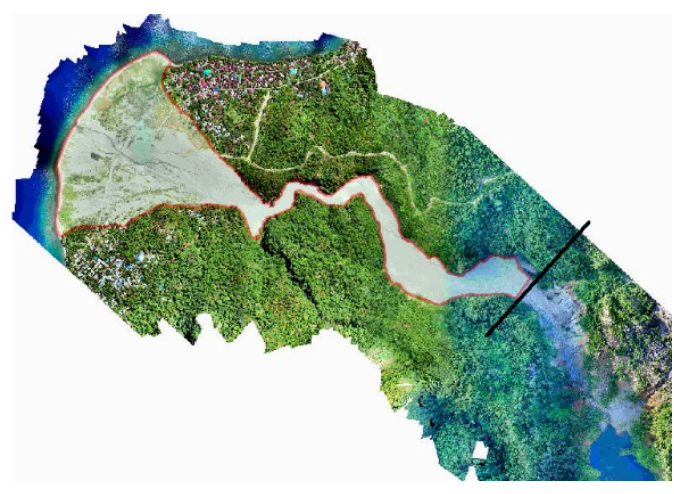

(b) After dam failure.

Fig. 3. Orthophoto inunduation image.

The images before and after dam failure are shown in Figure 3 . The urban areas affected by flood due to the dam failure is approximately $147,749.8 \mathrm{~m}^{2}$.

\subsection{Land Cover}

In this study the land cover is used to define the Runoff coefficient (C). The Way Ela Watershed Land is covered by forest with Runoff coefficient is 0.5 [9].

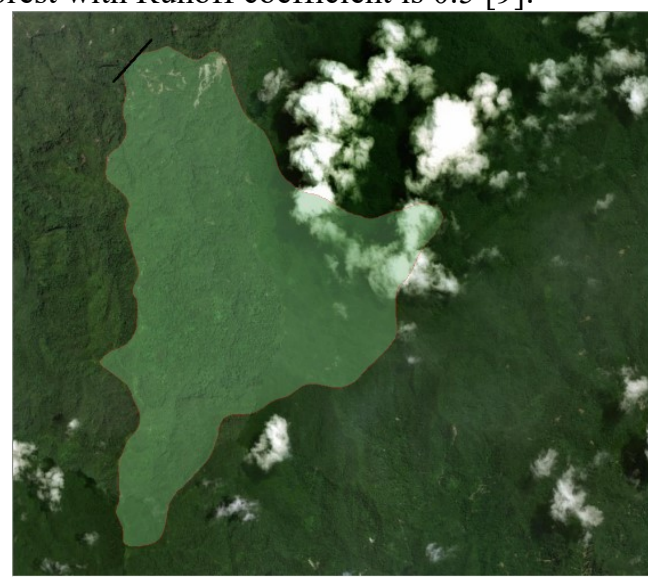

Fig. 4. Land cover map of the study area

\subsection{Reservoir Routing}

The reservoir routing was calculated using HEC-HMS to estimate the amount of discharge when the dam failed. There are three main parameters used as the input for reservoir routing in HEC-HMS, inflow, reservoir bathymetry and the dam failure scenarios. The output from this reservoir routing is the outflow discharge due the failure of Way Ela Natural Dam.

Table 1. HEC-HMS data used.

\begin{tabular}{|c|c|}
\hline Data & Values \\
\hline Watershed Area $\left(\mathrm{m}^{2}\right)$ & 12.56 \\
\hline River Length $(\mathrm{m})$ & 6.85 \\
\hline $\begin{array}{c}\text { Land Cover (Runoff } \\
\text { Coefficient) }\end{array}$ & 0.5 \\
\hline Inflow Hydrograph & Figure 4 \\
\hline Dam Top Elevation $(\mathrm{m})$ & +215.66 \\
\hline
\end{tabular}




\begin{tabular}{|c|c|}
\hline Data & Values \\
\hline Dam Top Length $(\mathrm{m})$ & 300 \\
\hline Normal Water Level $(\mathrm{m})$ & +197 \\
\hline
\end{tabular}

\subsubsection{Inflow}

The inflow of the reservoir was calculated using rainfall at the time of the dam failure. The condition of this inflow at the time of dam failure was estimated with SynderAlexeyev Synthetic Unit Hydrograph based on the characteristic of the catchment area as given in table 1 .

The rainfall detected at the dam failure by Ambon Meteorological Agency (BMKG) was $432 \mathrm{~mm}$. The results are shown in the Figure 5 along with the capacity of the spillway of the natural dam. It shows that inflow exceeds the spillway capacity.

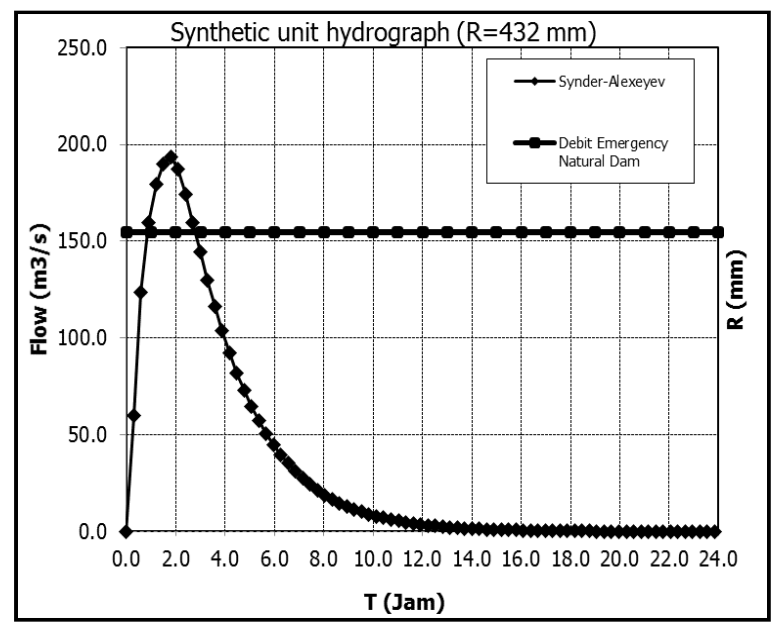

Fig. 5. Inflow hydrograph

\subsubsection{Reservoir Bathymetry}

Reservoir Bathymetry of the Way Ela natural dam was analyzed based on previous studies [7], the result is given in figure 5 along with the dam elevation (table 1).

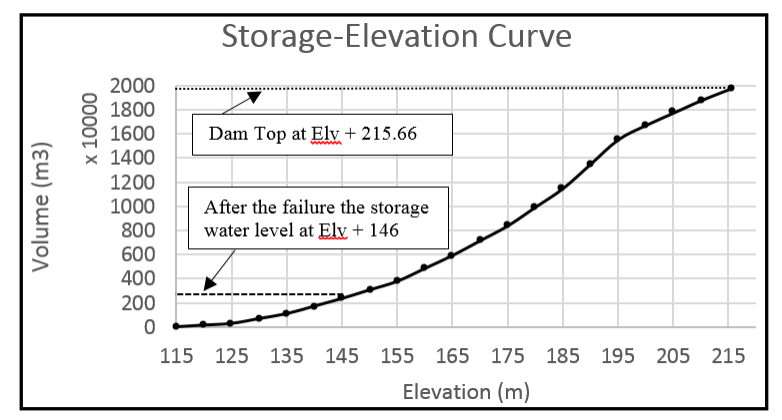

Fig. 6. Storage-Elevation curve

Figure 6 shows the maximum storage capacity of the reservoir is $19.807,000 \mathrm{~m}^{3}$ and after the dam failure the volume of water becomes $2,500,000 \mathrm{~m}^{3}$.

\subsubsection{Dam Failure Scenario}

In this study a simulation was conducted for the dam failure with the assumption that the failure was caused by overtopping based on previous studies [7].

Table 2. HEC-HMS data used.

\begin{tabular}{|c|c|}
\hline \multicolumn{2}{|c|}{ Overtopping } \\
\hline Top Elevation (m) & 215.66 \\
\hline Bottom Elevation (m) & 115 \\
\hline Bottom Width & 201.32 \\
\hline Left Slope (xH : 1V) & 1 \\
\hline Right Slope (xH : 1V) & 1 \\
\hline Development Time (HR) & 10 \\
\hline Trigger Elevation (m) & 200 \\
\hline
\end{tabular}

The scenarios parameter is given in table 2. The trigger elevation is set to $+200 \mathrm{~m}$, is $3 \mathrm{~m}$ above spillway $=197 \mathrm{~m}$, because based on chronology when the dam failure sliding occurs on the dam body because the spillway only finishes $70 \%$ and then collapses. The dam failure development time is 5 hours but lengthened to 10 hours due to emergency spillway [7]. The Bottom Width parameter is $2 \times$ dam height [10].

\subsection{Flood Propagation Model}

The 2D flood propagation was modeled using HEC-RAS v5. The HEC-RAS v5 solves the full 2D Saint Venant equations [11]:

Continuity Equation

$$
\frac{\partial \zeta}{\partial \tau}+\frac{\partial p}{\partial x}+\frac{\partial q}{\partial y}=0
$$

Momentum Equation :

$$
\begin{aligned}
& \frac{\partial p}{\partial \tau}+\frac{\partial}{\partial x}\left(\frac{p^{2}}{h}\right)+\frac{\partial}{\partial x}\left(\frac{p q}{h}\right)= \\
& -\frac{n^{2} p g \sqrt{p^{2}+q^{2}}}{h^{2}}-g h \frac{\partial \zeta}{\partial \tau} \\
& +p f+\frac{\partial}{p \partial x}\left(h \tau_{x x}\right)+\frac{\partial}{p \partial y}\left(h \tau_{x y}\right)
\end{aligned}
$$

where $\mathrm{h}$ is the water depth $(\mathrm{m}), \mathrm{p}$ and $\mathrm{q}$ are the specific flow in the $\mathrm{x}$ and $\mathrm{y}$ directions $\left(\mathrm{m}^{2} / \mathrm{s}\right)$, is the surface elevation $(\mathrm{m}), \mathrm{g}$ is the acceleration due to gravity $(\mathrm{m} / \mathrm{s}), \mathrm{n}$ is the Manning resistance, is the water density $\left(\mathrm{kg} / \mathrm{m}^{3}\right), \mathrm{xx}$, yy and xy are the components of the effective shear stress and $\mathrm{f}$ is the Coriolis $\left(\mathrm{s}^{-1}\right)$. The manning roughness is estimated for each type of land cover as given in the table and figure bellow. 


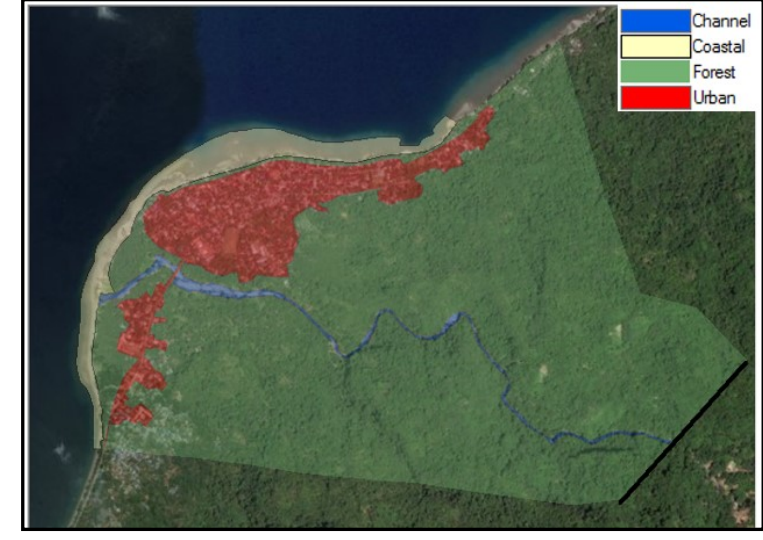

Fig. 7. Manning distribution map of study area

Table 3. Manning's Roughness

\begin{tabular}{|c|c|}
\hline Land Cover & Manning's $\boldsymbol{n}$ \\
\hline Forest & 0.03 \\
\hline Channel & 0.025 \\
\hline Coastal & 0.025 \\
\hline Urban & 0.172 \\
\hline
\end{tabular}

Source : Kotani, et. al. [12], chow [13], Gibson [14]

In order to ensure the stability of the model, the time step was estimated according to the Courant-FriedrichsLewy condition :

$$
C r=\frac{c \Delta t}{\Delta x}=\frac{\sqrt{g h} \Delta t}{\Delta x} \leq 1
$$

Based on the dam failure the overtopping failure will be modeled. The model results will be compared with the past inundation from the image (orthophoto). The inundation orthophoto is given in Figure 3.

Table 4. HEC-RAS Parameters

\begin{tabular}{|c|c|}
\hline Data & Values \\
\hline $\begin{array}{c}\text { Outflow } \\
\text { Hydrograph } \\
\text { Bpstream } \\
\text { Boundary) }\end{array}$ & $\begin{array}{c}\text { From Reservoir } \\
\text { Routing }\end{array}$ \\
\hline $\begin{array}{c}\text { Stage } \\
\text { Hydrograph } \\
\text { (Downstream } \\
\text { Boundary) }\end{array}$ & 0 \\
\hline $\begin{array}{c}\text { Digital } \\
\text { Elevation Model } \\
\text { (Terrain) }\end{array}$ & $30 \mathrm{~m} \times 30 \mathrm{~m}$ \\
\hline $\begin{array}{c}\text { Land Cover } \\
\text { (manning's } n \text { ) }\end{array}$ & Table 1 \\
\hline$\Delta t$ [s] & 0.5 \\
\hline$\Delta x$ [m] & 10 \\
\hline $\begin{array}{c}\text { Simulation } \\
\text { Period (day) }\end{array}$ & 1 \\
\hline
\end{tabular}

\section{Result and Discussion}

\subsection{Reservoir Routing}

Outflow from dam failure is simulated uses HEC-HMS. The overtopping failure scenario is selected refers to previous study [8]. Inflow Hydrograph was analyzed using the Synder-Alexeyev Synthetic Unit Hydrograph. The result of this routing process will be shown by Figure 7.

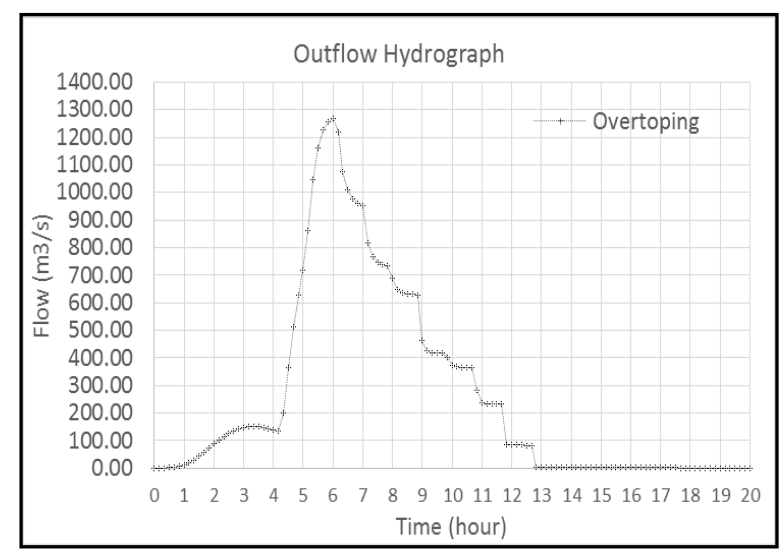

Fig. 8. Outflow hydrograph due the dam failure

Figure 8 shows the outflow peak discharge due the dam failure by the overtopping failure is $1,268.4 \mathrm{~m}^{3} / \mathrm{s}$.

\subsection{Flood Depth}

The relative error of overtopping failure shown in Table 5. Table 5 shows the result that this overtopping failure has a small relative error compared with the inunduation of the orthphoto image. It can be concluded that the previous dam failure was caused by overtopping. Time requirement to execute this model is 30 minutes.

Table 5. Flood Area

\begin{tabular}{|l|c|c|c|}
\hline & \multirow{2}{*}{$\begin{array}{c}\text { Way Ela } \\
\text { Village }\end{array}$} & \multicolumn{2}{|c|}{ Inunduation } \\
\cline { 3 - 4 } & $\begin{array}{c}\text { Urban } \\
\text { Area }\end{array}$ & Orthophoto & HEC-RAS v5 \\
\cline { 3 - 4 } & & & Overtopping \\
\hline $\begin{array}{l}\text { Area } \\
(\mathrm{m} 2)\end{array}$ & $404,945.33$ & $147,749.38$ & $147,132.91$ \\
\hline Area (\%) & - & 36.49 & 36.33 \\
\hline $\begin{array}{l}\text { Relative } \\
\text { Error } \\
(\%)\end{array}$ & - & - & 0.42 \\
\hline
\end{tabular}




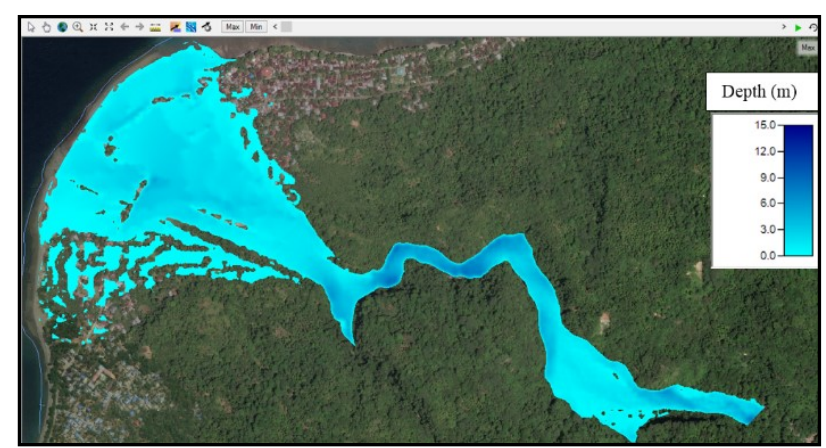

Fig. 9. Flood depth map

Figure 9 shows the maximum depth of flood inundation. In general, the depth agrees well with report provided by BNPB [1]. The maximum depth in the village area are between 3-6 m, the depth of flood in the upstream near the dam is 3-8 $\mathrm{m}$, and in the middle of the channel, the depth flood inundation is quite high 3-7 $\mathrm{m}$ due to its topographic condition which is a cliff.

\subsection{Flood Arrival}

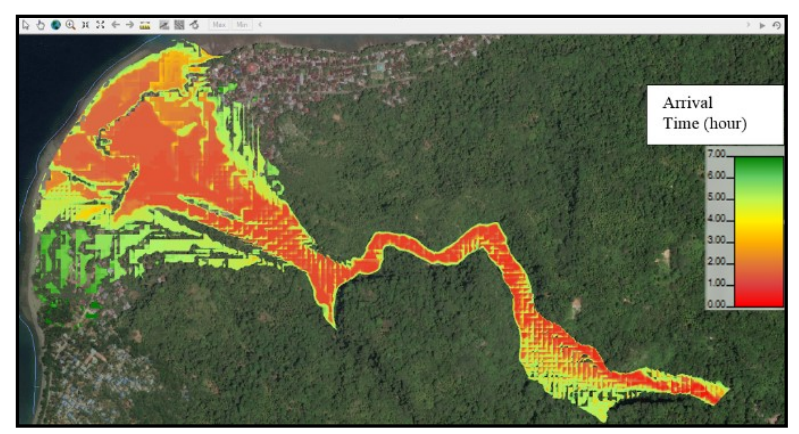

Fig. 10. Flood arrival time map

Figure 10 shows that the arrival time of the flood caused by the dam failure when it reaches the village is between 2 hours and in the downstream is between 5-5.5 hours.

\section{Conclusions}

A two-dimensional (2D) numerical model, HEC-RAS v.5, is used to simulate the over land flow generated by a dam failure. The dam failure itself is simulated using HECHMSv.4. The model was applied to the dam break case of the Way Ela natural dam.

The results from the study are the inundation area, depth, and arrival time. The inundation area was verified using the data from orthophoto. It was found that both areas corresponds well with a very small relative error $(0.42 \%)$. The inundation depth in the village there are up to $6 \mathrm{~m}$, which agrees well with the reported depth. The arrival time of the flood is 2 hours. These informations are very important to propose a mitigation plans with respect to possible dam break in the future.

\section{References}

1. S.P. Nugroho, Sebagian Bendungan Way Ela di Maluku Jebol, http://www.bnpb.go.id/ (25 July 2013)

2. C. S. Chen, T. W. Lin, C. Y. Chen, Eng. Geol. 188, pp. 148-158, (2015).

3. Y. Xiong, J. Water Resource Prot. 3, pp. 370-379, (2011).

4. K.Srinivas, M. Werner, N. Wright, Comparing forecast skill of inundation models of differing complexity-the case of Upton upon Severn, Flood risk management : research and practice, Issue ISBN 978-0-415-48507-4, (2009)

5. D. Wirustyastuko, J. Nugroho, Jurnal Teknik Sipil ITB 20, pp 129-140, (2013)

6. Rachmadan, C.R., Juwono, P.T., Asmaranto, R., Analisa Keruntuhan Bendungan Alam Way Ela dengan Menggunakan Program Zhong Xing HY21, http://pengairan.ub.ac.id/, (1 March 2014)

7. Balai Wilayah Sungai Maluku Kementrian Pekerjaan Umum Republik Indonesia, Final Report Investigasi Pekerjaan Bencana Alam Natural Dam Way Ela Negeri Lima, Kab. Maluku Tengah, PT. LAPI ITB, (2014)

8. G.W. Brunner, 2D Modeling and Mapping with HEC-RAS v.5 Monticello Dam Breach. US Army Corps of Engineers, (2015)

9. R.K. Sivanappan, Soil and water conservation and water harvesting, $\mathbf{2}^{\text {nd }}$ ed, Madras : Tamil Nadu Social Forestry Project, Indo-Swedish Forestry Coordination Programme, (1992)

10. F.A. Johnson, P. Illes, A Classification of Dam Failures. Water Power and Dam Construction, pages 43 -45, (1976)

11. V. M. Quiroga, S. Kure, A. Mano, IAHR 36 ${ }^{\text {th }}$, pp. 2533, (2015)

12. M. Kotani, F. Imamura, and N. Shuto, JSCE 45, pp. 356-360, (1998)

13. V.T. Chow, Open-Channel Hydraulics. (McGrawHill Book Company, New York. p.113. 1959)

14. S. Gibson, Unsteady HEC-RAS Model of the Downtown Reach of the Truckee River, HEC, PR-58, 39 p., (2005) 